\title{
Medieval archaeology and theory: a disciplinary leap of faith
}

Book or Report Section

Published Version

Gilchrist, R. (2009) Medieval archaeology and theory: a disciplinary leap of faith. In: Gilchrist, R. and Reynolds, A. (eds.) Reflections: 50 Years of Medieval Archaeology, 19572007. Society for Medieval Archaeology Monographs (30). Maney, Leeds, pp. 385-408. ISBN 9781906540715 Available at https://centaur.reading.ac.uk/1698/

It is advisable to refer to the publisher's version if you intend to cite from the work. See Guidance on citing.

Published version at: https://www.taylorfrancis.com/books/e/9781315089034

Publisher: Maney

All outputs in CentAUR are protected by Intellectual Property Rights law, including copyright law. Copyright and IPR is retained by the creators or other copyright holders. Terms and conditions for use of this material are defined in the End User Agreement.

\section{www.reading.ac.uk/centaur}

\section{CentAUR}

Central Archive at the University of Reading 
Reading's research outputs online 


\section{CHAPTER I 9 \\ MEDIEVAL ARCHAEOLOGY AND \\ THEORY: A DISCIPLINARY LEAP \\ OF FAITH}

By Roberta Gilchrist

This paper challenges the view that medieval archaeology has failed to engage with theory, exploring the impact over the last 25 years of processual and post-processual approaches. Trends are reviewed according to regional research traditions, chronological periods and research themes. It is concluded that processualism encouraged grand narratives on themes such as trade, the origins of towns and state formation, while the postprocessual concern with agency and meaning has fostered study of social identity, gender, religious belief, sensory perception and spatial experience. It is argued that processualism created an artificial dichotomy between economic/scientific approaches on the one hand, and social/theoretical approaches on the other. The potential is discussed for medieval studies of embodiment, materiality, agency and phenomenology, and the case is made for greater engagement with the development of theory in the wider discipline, with the aim of achieving a more meaningful medieval archaeology.

\section{INTRODUCTION}

In 1982 , the occasion of the Society's $25^{\text {th }}$ anniversary prompted reflection on the discipline's relationship with archaeological theory. 'New Archaeology' had transformed the wider subject in the I970s, and among its significant achievements was demonstration of the role played by explanatory philosophical frameworks in all aspects of archaeological data-collection and interpretation. Richard Hodges, in particular, called for medieval archaeologists to abandon their culture-historical paradigm, with its inclination to small-scale particularization. In its place, he advocated processual approaches based on systems theory and model-building, emphasizing the importance of internal and external processes in transforming societies (Hodges I983). He challenged the comfortable, empirical stance of medieval archaeology and encouraged bigger and bolder questions - the medieval 
archaeologist as 'parachutist' rather than 'truffle-hunter' (Hodges I989). ${ }^{1}$ Twenty-five years later, and on the occasion of the Society's 5oth anniversary, the time is ripe to revisit the relationship between medieval archaeology and theory. How has our discipline engaged with significant advances in archaeological thought since I982? Has archaeological theory changed the way we interpret the Middle Ages?

\section{THE LONG SHADOW OF PROCESSUALISM}

The practice of medieval archaeology is sometimes characterized as anti- or a-theoretical, with exponents favouring allegedly 'common sense' or 'functionalist' approaches (Gerrard 2003, I73, 218). Matthew Johnson has commented on this tendency especially within medieval landscape archaeology: the inherent proposition is that archaeological features in the landscape are recorded objectively and therefore take on the status of facts that speak for themselves; the role of theory in mediating interpretation is rejected in favour of an empiricist position (Johnson 2007, 83). Johnson and others have demonstrated the extent to which apparently objective methods of archaeological data-collection are in fact socially constructed and 'deeply theoretical' (ibid, 93). For example, he notes that standard means of landscape recording - the hachured plan, the Ordnance Survey map and the aerial photograph - all present a bird's-eye view of the landscape from above. This prioritization of the plan view takes no account of how people in the past would have perceived and moved through the landscape; moreover, it fails to acknowledge the extent to which ostensibly objective methods of data-recording are selective, and imbued with modern value judgements. Archaeological observations are theory-laden, and intensely dependent on extended networks of theoretical claims and assumptions (Wylie 2002, 6).

It may be argued that the empiricist position in medieval archaeology was reinforced by the positivist methodologies of processualism, which perpetuate a separation of theory and data. Until the advent of New Archaeology in the I97os, culture-history was the prevailing 'paradigm' in world archaeology, a tradition associated with the mapping of specific cultures and their influence, with no attempt to explain underlying meanings or trends in material culture. ${ }^{2}$ Processualism constituted a 'scientific revolution' in archaeology, and has duly taken its place as the subject's prevailing paradigm. ${ }^{3}$ New Archaeology appeared to offer a more objective, science-based method to the youthful discipline of medieval archaeology, one still struggling to come to terms with its parent discipline of history ${ }^{4}$ (Gerrard 2003, I74). The hypothetico-deductive approach was first applied to medieval archaeology by Martyn Jope, entailing the testing of interpretations through quantification, mapping and modelling of data (Jope I972). In summary, then, the term 'empiricism' has acquired two distinct meanings in medieval archaeology: the 'empiricist position' that archaeological data are facts that speak for themselves; and the positivist methods of data analysis that are associated with processualism.

The more ecological tenets of New Archaeology, developed by Eric Higgs at Cambridge in the I960s, remain important today (eg Williamson 2003): the application of environmental and materials sciences helped to carve a distinctive niche for archaeology in medieval studies. Influenced by processualism, medieval archaeology 
has specialized in topics neglected by conventional documentary sources, including landscape, subsistence, diet, industry, technology, and the tenements and crofts of 'the common man's of the medieval town and countryside. When the Society drew up its recommendations for research in 1987 , greatest confidence for an archaeological contribution to medieval studies was in the realm of landscape economy and technology. For example, in relation to religious sites, it was proposed that ritual foci were no longer a priority; instead, we needed 'more information on the non-claustral areas of the Christian institutions, to examine their impact upon the economy and society of their surrounding region, and the investments made in agriculture and industry, both in the immediate area of the monastery and in its distant farms and granges' (SMA I987, 4). Undoubtedly, this approach has advanced our understanding of monastic landscapes (see Bond 2004). Perhaps ironically, however, the period of the last 20 years has also seen some of the discipline's most important theoretical analyses directed specifically toward the ritual core of churches, cloisters and other religious sites (discussed below). In striving to consolidate its own identity within medieval studies, archaeology has tended to prioritize more economic enquiries, and to place greatest value on empirical evidence that appears more scientifically robust. An indirect legacy of processualism was the creation of an artificial dichotomy between economic/scientific approaches on the one hand, and social/theoretical approaches on the other.

Processualism impacted more overtly on early medieval archaeology (c6th to Ioth centuries AD), an epoch relatively unfettered by documents. The comparative paucity of historical sources perhaps encourages more ambitious theoretical reflection on subjects such as early medieval state formation and the origins of feudalism (eg Randsborg I980; I99I). The work of Richard Hodges was an exciting and radical departure, with Dark Age Economics (I982) addressing the origins of towns and longdistance trade networks. Its title signalled an alliance with the economic systems theory of Marshall Sahlins' Stone Age Economics (1974), proposing the thesis that trade networks in prestige goods were stimulated by political leaders such as Charlemagne and Offa, the medieval equivalents of Sahlins' tribal 'big-men'. ${ }^{6}$ The explicit use of systems theory was short-lived in medieval archaeology, with the timing of Hodges' pioneering works coinciding almost precisely with the demise of processualism (in Britain, at least). Although seldom explicitly cited in interpretations today, processualism underpins much archaeological research on the role of politics and consumption in the formation of early medieval elites. For example, Martin Carver adopts the theme 'monumentality' as shorthand for investment in burial mounds, jewellery, churches, sculpture and illuminated manuscripts, which he regards as tangible fossils of the political language of early medieval Europe (Carver 200I).

\section{THEORY IN MEDIEVAL ARCHAEOLOGY: THE LAST 25 YEARS}

The influence of processualism in the wider subject of archaeology began to wane in the late I970s and early I980s, with challenges to the apparent objectivity of New Archaeology's methods, and calls for more anthropological approaches to interpretation. Ian Hodder was at the vanguard of these developments, experimenting 
with ethnoarchaeology and applying structuralist principles based on the premise that material culture is governed by grammatical rules similar to those of language (Hodder I982a; I982b). By the mid-I980s, cross-cultural approaches were beginning to be rejected in favour of contextual, historically grounded readings of archaeology, and a diversity of interpretative approaches drew inspiration from fields including anthropology, philosophy, feminism, Marxism and cognitive science. Together, these approaches are often termed 'post-processual'. As Matthew Johnson has emphasized, there is no unified post-processual paradigm, but common strands can be identified. Post-processualists take a social constructivist perspective in challenging scientific claims to unique and objective knowledge; they offer hermeneutic interpretations that focus on the meanings of material culture; and they stress agency, the active strategies of individuals to reproduce or transform their social contexts (Johnson I999, IOII04). To what extent have these approaches influenced modes of interpretation in medieval archaeology?

By the early I990s, some medievalists were calling for studies of agency and the active role of material culture in structuring social relations (Moreland I99I). But the engagement with post-processual theory has remained selective, with lines drawn according to geographical region, chronological periods and research themes. The appetite for archaeological theory can generally be seen to follow an AngloScandinavian axis, and medieval archaeology is no exception in showing more rapid theoretical development in Nordic- and English-speaking areas. Medieval archaeology is commonly divided into at least two, and sometimes up to four, chronological subperiods of early and later medieval; for example, in Germany, the period is divided into the Early Middle Ages ( $c 450$ to the 8th century), Carolingian/Ottonian (9th to Ioth centuries), the High Middle Ages (c I000-I250) and the Late Middle Ages (c I250-I 500). As previously noted, early medieval archaeology has tended to embrace theoretical perspectives more warmly. It is significant that medieval archaeologists in Scandinavia have been especially successful in integrating theory; here, the Viking period connects the late Iron Age to the early medieval period (beginning in the IIth century AD). Adoption of the longue dureé ${ }^{7}$ merges Scandinavian prehistory seamlessly with the Middle Ages, promoting greater engagement with theoretical perspectives and yielding innovative work on topics such as cosmology, gender and childhood (eg Andrén et al 2006; Price 2002; Welinder I998).

More generally, medieval archaeologists have accepted the post-processual principle that material culture plays an active role in creating and sustaining the social world. Theory is implicit in the discipline's move towards social archaeology, as evidenced by contributions to the journal Medieval Archaeology. ${ }^{8}$ Explicitly theoretical articles are rare; for instance, David Hinton on 'closure theory' (I999), Howard Williams on monument reuse (I997) and Amanda Richardson on gender and space in the medieval English palace (2003). However, most issues of the journal now contain at least one empirical study which is broadly 'social', if not expressly theoretical (eg Dickinson 2005; Hamerow 2006; Clarke 2007).

The discipline of medieval archaeology has not developed a unifying or cohesive theoretical framework of its own, in contrast with some other chronological fields: notably the 'domestication' theme which has dominated post-processual Neolithic 
studies (Rowley-Conwy 2004), or the obsession of Roman theoretical archaeology with 'Romanization' (Hingley 2005). Theoretical contributions have developed largely within the confines of medieval archaeology's specialist or period groups (based on categories of monument or material), rather than through regular engagement with theory-building in the wider subject arena. The application of theory in medieval archaeology has remained highly contextual (or particularistic); this lack of interest in thematic theory-building may reflect the discipline's failure to acknowledge the political significance of interpretations of the Middle Ages to the present (see Biddick 1998). There have been occasional exceptions to this rule, for instance in the feminist development of global gender archaeology (Gilchrist 1999) and in debates about migrations and ethnicity (Härke I998).

Respective specialist groups and research themes in medieval archaeology have varied in their responsiveness to post-processual theories. Perhaps most receptive has been the field of burial archaeology, which has demonstrated a profound shift of thinking from the assumption that grave goods directly reflect the possessions of the dead, to the premise that grave goods were used to make statements about the social identity of the deceased. Processualist applications to burial archaeology included efforts to score the value of grave goods and assess the territorial location of graves through Thiessen polygons (eg Arnold I988). By the late I980s, such approaches were abandoned in favour of studies exploring the constitution of identities through funerary display. Identity is understood to be historically contingent, dynamic, and operating along multiple social axes, such as class, gender, ethnicity, age and religious status; identity is experienced internally by the individual, and is at the same time employed by society in defining external categories. Early medieval burial archaeology has investigated aspects of identity including warriorhood (Härke I990), gender (eg Halsall I996; Stoodley 1999; Hadley 2004), age (Stoodley 2000), regionalism (Lucy 2000) and ethnicity (eg Härke 2007). Commemorative monuments have been discussed in the post-processual terms of material culture as text - ranging from runestones as family monuments that invoked memory through their collective reading (Andrén 2000), to the burials at Sutton Hoo as a form of poetry or theatre, funerary tableaux which served as compositions to memorialize the life of the deceased (Carver I998). The rite of cremation has been conceptualized as a distinctively transformative technology with the power to alter identities and social relationships in death (Williams 2005; Gansum and Oestigaard 2004) (Figure 19.I). After 20 years of focus on the expression of social identity through early medieval funerary practices, there is currently a resurgence of interest in the role of emotion, religious belief and cosmology (eg Williams 2006; Kristoffersen and Oestigaard 2008; Hadley, this volume). Later medieval burial archaeology has taken longer to engage with theory, but recent studies have elucidated aspects of identity, memory, gender and agency (Williams 2003; Gilchrist and Sloane 2005; Gilchrist 2008).

A number of studies in buildings archaeology have drawn upon spatial theory to develop innovative readings of secular and religious architecture. Several have employed methods of formal spatial analysis based on the structuralist premise that, through patterns of physical access, space reproduces hierarchical social relations. The corresponding assumption is that space can be mapped in terms of a formal 


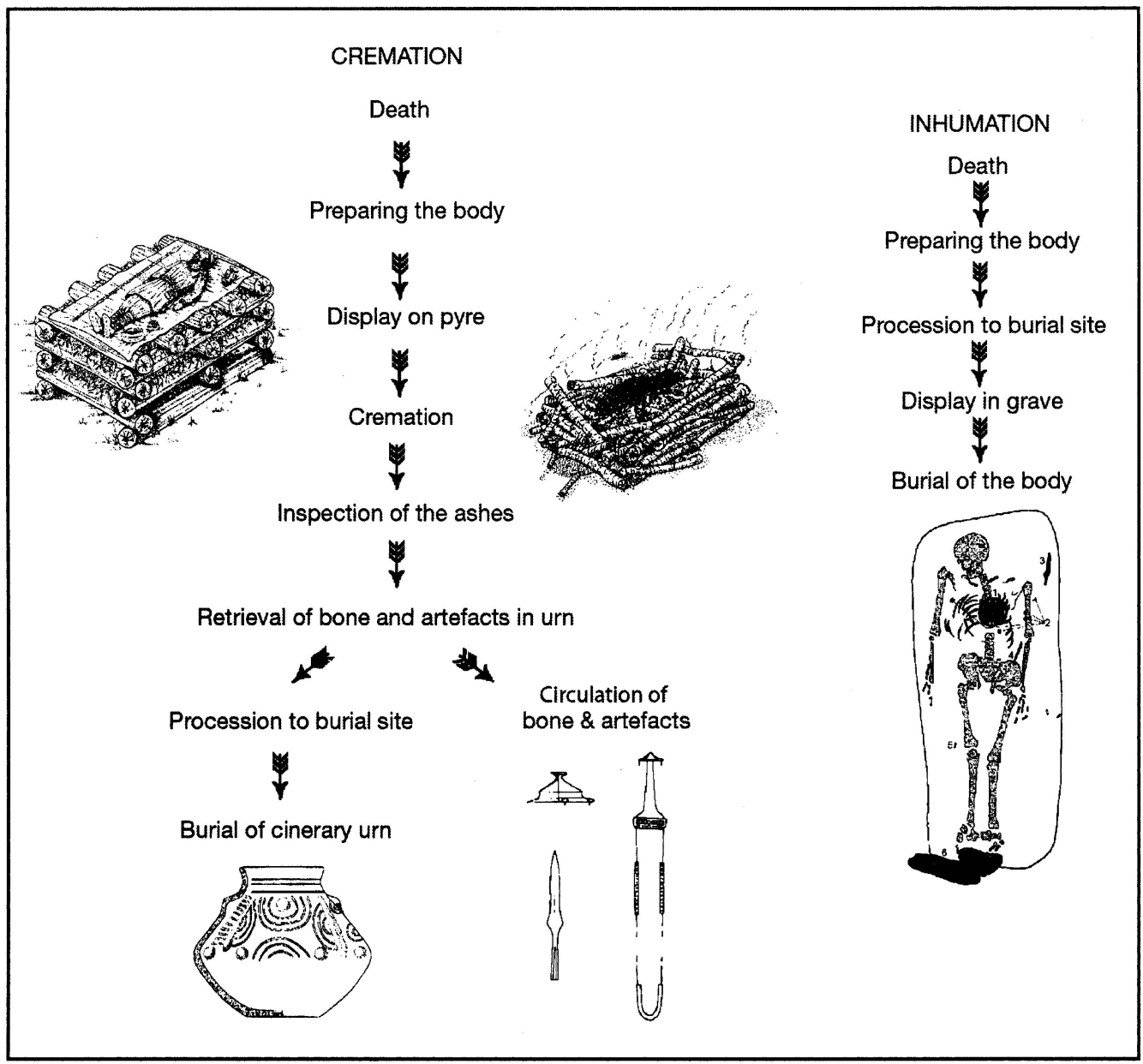

FIGURE I9.I A schematic representation of the different ritual sequences and social processes that accompanied early Anglo-Saxon cremation and inhumation rites. Howard Williams used this illustration to emphasize the contrasting roles of these two mortuary technologies in managing the powerful mnemonic agency of weapons. (Reproduced with permission from Williams 2005)

grammar and read to infer past social relations (eg Fairclough I992, based on Hillier and Hanson 1984). Applications of this approach to medieval material have tended to reject the cross-cultural assumptions of structuralism, and instead use the mapping method to explore specific historical questions. Formal spatial analysis can be criticized for its tendency to simplify the relationship between space and the expression of different types of social power; for its limitations in representing the culmination of numerous stratigraphic sequences as a single phase; and for its failure to address the sensory experience of space. Nevertheless, where these caveats are borne in mind, spatial analysis can be employed as a useful technique for comparative and problemoriented analysis. 
In his study of the rural house in later medieval England, Matthew Johnson rejected the typological approach that tends to characterize studies in vernacular architecture. Instead, he considered the meaning of the open hall to different groups in the household, discussing why this particular spatial format was pervasive and how it eventually changed with an increasing ideology of enclosure (Johnson I993). Johnson's book on later medieval English castles (2002) moved further away from any method of formal or typological analysis to consider phenomenological readings of castles - a category of monuments that is more typically examined in terms of the diffusion of military technology. His phenomenological perspective emphasized castles as stage settings for social elites, with masculine identities expressed through architectural design, layout and landscapes. ${ }^{9}$ Johnson's study contributed to the growing corpus of work on the symbolic and social dimensions of castles and their 'designed landscapes' (Dixon 1990; Everson 1996; Creighton 2002; Liddiard 2005; see Hansson, this volume).

The confrontation between processual and post-processual approaches in medieval archaeology has come to the fore in relation to the study of landscape and rural settlement. Johnson has critiqued landscape approaches for their intuitive, antitheoretical foundations, while he describes the research agenda of medieval settlement studies - and in particular its quest for village origins - as a 'taphonomic retreat'. He argues that medieval landscape archaeology exhibits less and less confidence in its ability to make meaningful statements about the past, thereby reinforcing its position as an ancillary discipline to history (Johnson 2007, II7-II9). He calls for more phenomenological studies that would reflect on how people moved across landscapes, and perspectives that would highlight agency, gender and the integration of religion within settlement studies - this experiential approach has been successfully demonstrated by Karin Altenberg (2003), in a comparative study of medieval marginality in southern Sweden and south-west England.

The initial reaction to Johnson's critique appears to reinforce the distance between theoretical and empirical medieval archaeology (see Rippon, this volume; Fleming 2007). Stephen Rippon's response is to restate the greater and more lasting value of meticulous empirical surveys over discursive theoretical works. Moreover, his assessment of medieval landscape archaeology sets up a tension between interpretations which privilege either social agency or environmental determinism as vectors of innovation and change. This is a false dichotomy which perpetuates the unfortunate split in medieval archaeology between economic/scientific and social/ theoretical approaches. Throughout the social sciences there have been efforts to reconcile rigorous empirical approaches with social constructivist foundations (eg Latour 2005). For example, the study of prehistoric landscapes has been influenced by Tim Ingold's 'dwelling perspective', which integrates ecological and phenomenological approaches to consider how people inhabit and interact with their environment (Ingold 2000). Ingold actually selected a medieval example to elucidate his point that the landscape becomes a record of the lives and work of people in the past. However, rather than look to medieval archaeology for source material, he focused on a painting by Pieter Bruegel the Elder. The Harvesters (I 565) depicts harvest-workers men, women and children - resting from their labours beneath the shade of a tree; 
this social scene is framed by the tower of the parish church and the panoramic view of the village and common fields in the distance. Ingold employs the painting as a device to reflect on 'being' in the medieval landscape, and to consider how the lifecycles of humans, plants, animals and monuments are woven into the texture and temporality of landscape (ibid, I98, 20I-206).

\section{MEDIEVAL MATERIAL CULTURE: TABULA RAS ${ }^{10}$}

The last few decades have witnessed a shift from purely typological studies of medieval material culture to more thematic expositions. For example, pioneering work has clarified the material culture of everyday life, including objects from the household and children's toys. Toys from medieval Novgorod (Russia) and Turku (Finland) were made from wood, clay, leather and bone, while miniature household items and toy-weapons made of lead/tin have been recovered from later medieval English towns (Rybina I992; Luoto 2007; Egan I998). David Hinton has surveyed the artefacts that people used to express social affiliation and status, such as jewellery, drinking-vessels and tableware, to chronicle change from the 5 th to the 15 th century (Hinton 2005). He adopts the perspective of 'closure theory', which contends that a ranked society operates through competing groups which use material culture as one means of excluding others from membership. The material culture of dining has been considered more widely in terms of social etiquette and cultural preferences for certain table and kitchenwares (eg Brown 2005; Hadley 2005). A phenomenological analysis of these same materials has stressed the significance of sensual factors such as texture, colour and shape in the perception and use of everyday material culture (Cumberpatch 1997).

Post-colonial theory has begun to influence archaeological discussions of medieval migrations, for example in reconsiderations of the Viking expansion as a Scandinavian diaspora (Barrett 2008). ${ }^{11}$ Controversially, Lotte Hedeager has reinterpreted the appearance of Germanic animal styles in Nordic art in the 5th and 6th centuries as evidence for the expansion of the Huns into Scandinavia (Hedeager 2007). Pottery has also been evaluated for its potential to address ethnic and cultural identity, for instance in David Gaimster's model of a proto-colonial, Hanseatic culture based on networks of mercantile exchange permeating from later medieval Germany (Gaimster I999). This approach has recently been critiqued from the perspective of post-colonial theory, using a case study of medieval Turku to argue instead for local hybridity and interaction between German merchants and Finnish townspeople (Immonen 2007). Colonialism has also been addressed through animal bone studies, in Naomi Sykes' comparative analysis of assemblages from Norman England and northern France. She argues that Norman colonialization involved the intensification of hunting culture, with the plantation of parks and forests, increased exploitation of 'wild' species and the introduction of exotic species such as peafowl, rabbits and fallow deer (Sykes 2007). Isotopic analysis of human remains has also been harnessed to explore ethnic foodways: increased consumption of marine foods in Orkney has been linked to Norse colonization (Barrett and Richards 2005). 
Contextual studies of medieval artefacts have made connections with wider discourses of popular culture and ritual practice. For example, Anders Andrén's reading of the iconography of Gotlandic picture stones (Sweden, AD 400-IIOO) links them with forms of narrative used also in the construction of ship burials and funerary rites. The stones were not grave markers but instead monuments placed on boundaries within the landscape. Those dating from $c 800-$ I 100 were shaped like keyholes or mushrooms, and were decorated with a rich repertoire including ships, armed horsemen, women with drinking horns, battle scenes and animals. Andrén interprets the picture stones as 'doors' and links them with the symbolism of hearth and home, metaphoric representations which mediated between the worlds of the living and the dead (Andrén I993). Mark Hall has traced the context of an ivory knife handle from I4th-century Perth, Scotland (Figure I9.2), demonstrating how a single artefact can illuminate an entire cultural milieu. He argues that this particular rendition of the Green Man, with foliage protruding from his ears, eyes and mouth, may allude to sins, or alternatively, to processes of rebirth and regeneration represented by the
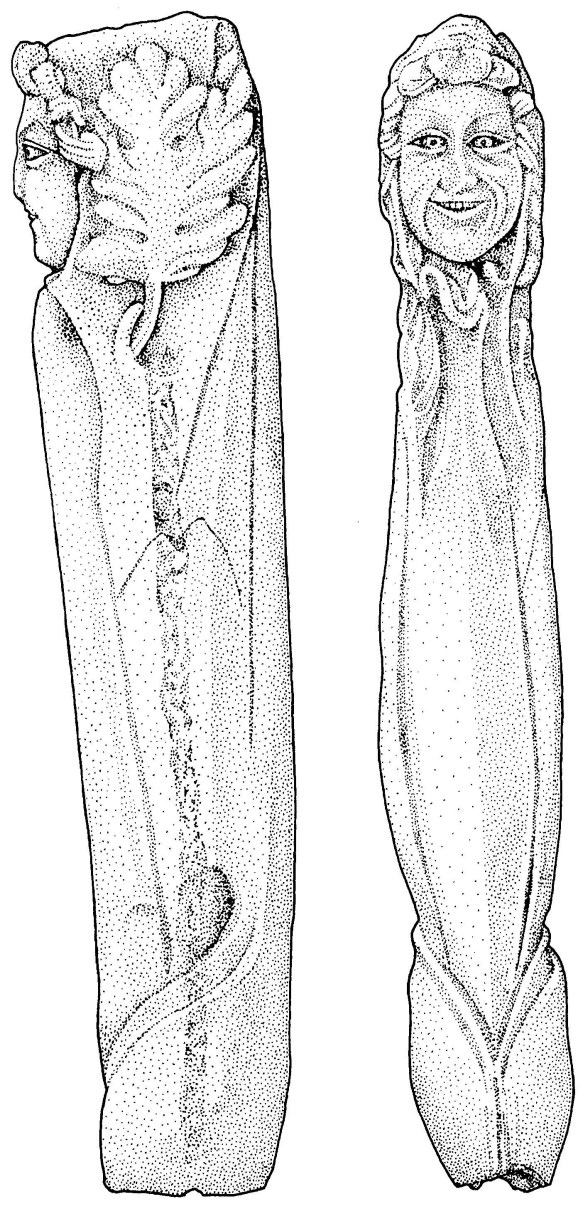

FIGURE I9.2 The Green Man ivory knife handle from Perth was made in the I 4 th century. Mark Hall has interpreted its iconography as having been connected with seasonal civic ritual such as May Day celebrations. (Reproduced with permission from Hall 200I) 
emerging greenery. He suggests that this object is connected with the cultural imagery of religious and secular pageantry, and especially with the popular celebration of May festivities (Hall 200I).

In general, however, there has been little explicit theorization of medieval material culture in terms of identity or social practice. Discussion of the body and sexuality has been notably absent (although see Nøttveit 2006, for a discussion of the

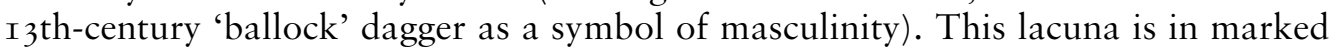
contrast with perspectives on embodiment that have been advanced in other areas of historical archaeology (eg Meskell and Joyce 2003), and with art-historical glosses on 'sexual' material culture such as medieval 'erotic' lead badges (Jones 2002, 248273). This omission is particularly surprising, given the wealth of catalogued dress accessories from medieval settlements, and the thousands of actual bodies excavated as skeletons from medieval cemeteries. Osteological approaches tend to follow clinical models in assigning the age, sex and pathology of individuals in order to discuss general patterns of health and lifestyle in broad social groups. Although the specific historical contexts of health are explored, the social and experiential practices which create bodies tend to be neglected (Sofaer 2006). While the human body has yet to be theorized in medieval archaeology, zooarchaeologists have conceptualized animal bodies as material culture, exploring aspects of materiality, symbolism and human-animal interactions (eg Pluskowski 2007).

The approach of artefact biographies (after Kopytoff I986) has been applied especially to medieval pictorial artefacts with complex life histories, such as sculpture (Stocker and Everson 1990), standing crosses (Moreland 1999) and Pictish symbol stones (Clarke 2007). Medieval archaeologists have been less eager to apply the themes of materiality and artefact agency that have characterized recent research on prehistoric material culture. 'Materiality' is often taken to refer to the quality of the object or 'thing', its 'thinginess', or more broadly to the 'socialness' of things. But materiality also takes account of how human sensory engagement with the material world of objects shapes cultural experience (eg Tilley 2006). The concept of artefact agency developed from the 'aesthetics' approach of Alfred Gell (I992), ${ }^{12}$ which explores the appeal of objects in their historical context. The formal qualities of certain things are said to effect an 'enchantment' that can influence social action and from this it is argued that artefacts possess some form of agency (Gosden 200I). It would be helpful if these debates distinguished more clearly between 'animate' and 'inanimate' agency: animate agents are able to 'do something' or 'to act intentionally', while inanimate agents, such as artefacts, have the potential 'to act on other things' (Hacker 2007, I24, original italics). The agency of artefacts may not be intentional, but it has consequences nevertheless.

Tim Ingold has recently challenged these approaches by arguing that things are not active because they are imbued with agency, but because of the meanings of certain materials used in their production. He has called for greater attention to the properties of materials rather than the intrinsic materiality of objects (Ingold 2007). Medieval archaeologists are strongly placed to bring more robust discussions of causality to these debates. The historical framework contributes sophisticated insights to the meanings of materials and their perceived agency, for example the special 
properties of the relics of saints, healing gems, or the unicorn's horn (ie the narwhal's tusk: Pluskowski 2005). Within the framework of medieval rationality, the animate bones of saints are able to do something through divine agency, while the occult power of nature gave some inanimate objects and materials the inherent potential to act on other things. Inscriptions on medieval artefacts sometimes link them to the intentional agency of named individuals who made or commissioned them, such as the famous 9th-century Alfred Jewel (Aelfred mec heht gewyrcan, 'Alfred ordered me to be made'). In this case, Alfred's agency to act is personified through anthropomorphic representation: through a process of objectification, the agency of persons and things become entwined (Gell I992; Tilley 2006, 63).

But we should also take inspiration from the imaginative approaches to materiality and meaning that prehistorians have developed. For example, interpretations of henge monuments have been influenced in recent years by concepts of the materiality of stone (Parker Pearson and Ramilisonina 1998). The argument is that henges were constructed in wood for ceremonial use by the living community and in stone to commemorate the dead. Stone monuments are understood to be the end-stage of a process of 'hardening' that is associated with the ancestral dead; the contrasting materials of timber and stone represent the metaphorical transformation of flesh to bone. We might apply similar insights to the 'great rebuilding' of parish churches c1050-II 50, involving their translation from timber to stone. This process has been discussed variously in terms of chronology, technology, architectural style and cultural affiliation, but scant reflection has been given to the cultural meanings embodied by this massive replacement of materials. Until c950, only cathedrals and important monastic churches were likely to have been built of stone; many parish churches have their origins in the wooden chapels constructed by local lords and only gradually gained parochial status (Morris I989, I65). It may be suggested that the translation from timber to stone represents a new cycle in the life of the parish church, one commemorated in materials of greater durability. Stone as a substance may have held the promise of spiritual eternity: its light-coloured hue and dense crystalline structure would have contrasted sharply with the dull, perishable timber used for the houses built and occupied by parishioners. These timber-framed dwellings were replaced generationally, while the masonry of the parish church would have symbolized the enduring permanence of the community of saints. The transition to stone in the IIth century was also bound up with the increasing influence of Rome in church affairs: stone was a 'petrine' material, referring literally and metaphorically to both rock (Petrus) and St Peter (D Stocker, pers comm). The materiality of parish churches was achieved through the reuse of Roman materials, by building in stone, and by adopting the Romanesque style - all of which evoked the Roman past and strengthened the contemporary connection to the papacy (Eaton 2000; Stocker and Everson 2006, 57).

PARISHES AND PARADIGMS: THE THEORIZATION OF CHURCH ARCHAEOLOGY?

I would like to look in more detail at the impact of theory on one branch of medieval archaeology over the past 25 years - and church archaeology may seem an 
unlikely candidate. The systematic recording and dating of church fabric commenced in the early I9th century, in association with repair programmes to cathedrals and churches and through the innovation especially of John Britton and Thomas Rickman. In contrast, the archaeological excavation of churches did not begin in earnest until the I950s, with the clearance of bomb-damaged churches (Rodwell I997). By the I970s, genuine urgency drove the archaeological study of churches, spurred by contemporary concerns for their conservation. Dwindling congregations were resulting in redundancies and church closures, enabled by The Pastoral Measure 1968; due to the 'ecclesiastical exemption', these threatened monuments fell outside the protection of Ancient Monuments legislation (see Bianco 1993). Spearheaded by the Council for British Archaeology, the archaeological community was determined both to improve academic understanding of churches, and to provide adequate archaeological expertise to guide their conservation (Morris I983). Church archaeology emerged from a conservation platform to develop specialist archaeological methods suited to the recording of sites that combine multi-period elements of standing fabric, subsurface deposits and complex burial sequences.

Throughout the I980s and the early I990s, the study of churches matured into a vibrant field of medieval archaeology (eg Blair and Pyrah 1996). In many regions of Europe, church archaeology has rewritten our understanding of the historical origins of the parish church (eg Zadora-Rio 2003; Kristjánsdóttir 2004; FitzPatrick and Gillespie 2006), and its place within the broader physical landscape and canvass of settlement (Morris 1989; Blair 2005; Turner 2006). But today the term 'church archaeology' is generally used to encompass a suite of specialist techniques, or to describe programmes of recording carried out on ecclesiastical sites (Rodwell 2005). In effect, church archaeology has evolved as a specialist methodology rather than as an interpretative approach or as a cohesive research framework. In contrasting the aims of medieval archaeologists and architectural historians, Eric Fernie observed that church archaeologists were more concerned with unravelling techniques of medieval construction, while architectural historians aimed to discern subtleties of 'meaning' in ecclesiastical architecture (Fernie 1988; my italics). In his review of the global archaeology of Christianity, Paul Lane called for medieval church archaeologists to prioritize the 'meanings of religious spaces' and to take theoretical guidance from prehistorians (Lane 200I, I59-I6I; my italics). In particular, he advocated the development of an 'archaeology of cult', focusing on material evidence for four themes: attention to the supernatural, emphasis on boundaries between the human and spirit worlds, the presencing of a deity, and the performance of acts of worship and offerings to the supernatural (after Renfew and Bahn I99I, 359).

Can we therefore conclude that church archaeology is all 'method' and no 'meaning'? To the contrary, in the study of religious sites over the last 20 years, medieval archaeologists have developed precisely the insights called for by Lane's proposed 'archaeology of cult'. Church space has been reconsidered in terms of social, temporal and cosmological meanings (eg Graves 1989; Andrén 1999; Gilchrist 1999, 83-87; Giles 2000a). Liturgy has been reassessed according to patterns of physical access and movement within and around churches, the way in which light and human sight interacted with the mass, and how the sound of bells connected the living with 
the dead (Graves 2000; Roffey 2007; Stocker and Everson 2006). Visual and sensory approaches have reinterpreted wall-paintings in the parish and monastic church (Giles 2007; Graves 2007). The burial and reuse of church fonts has been explored in terms of their status as 'special' artefacts, expressed through the selection of materials and decoration (Stocker I997). The iconoclasm of the Reformation has been redefined within the framework of personhood, concluding that the attack on images of saints focused on particular parts of the body (Graves 2008). ${ }^{13}$ The creation and maintenance of boundaries has been clarified especially in relation to monastic space, with gender examined as habitus ${ }^{14}$ in the medieval nunnery (Gilchrist I994), and the precinct of the monastic cathedral charted in terms of experiencing and inhabiting space (Gilchrist 2005, 236-257) (Figure 19.3). A Marxist analysis of space has focused on the exercise of power in the precinct of the archbishop's palace at Trondheim (Norway) (Saunders 2002) and material culture has been mapped to identify the 'soft spaces of pilgrimage' in the monastic precinct of a Norfolk cult centre (Pestell 2005). Guildhalls have been analysed from the perspective of structuration theory, ${ }^{15}$ revealing the spatial paradox of an open space which symbolizes communal identity and fraternity, but which at the same time reinforces hierarchical divisions through corporate rituals (Giles 200ob). And medieval archaeologists have begun to integrate religion with studies of daily domestic life (as called for by Insoll 2004). For example, the persistence of folk beliefs can be discerned in the deliberate deposition of prehistoric lithics in medieval houses in northern Europe, ranging from Scotland to southern Sweden and Finland (eg Carelli i997; Hall 2005).

On closer examination, 'church archaeology' has undergone a startling theoretical transformation. There has been no overarching manifesto (as called for by Lane 200 I or Insoll 2004) but the medieval archaeology of religion has seen a slow 'scientific revolution'. Moreover, its individual proponents have successfully integrated postprocessual theory with rigorous empirical studies; the perceived divide between meticulous empirical scholarship and theoretical discourse has been dissolved by incremental degree. The reception of this body of work in the wider discipline is perhaps predictable - theoretical insights to medieval society are accepted only when the corpus of empirical evidence on which they are based has been thoroughly scrutinized in positivist terms. My own work on gender and medieval nunneries serves as one example: while welcomed by medieval historians and archaeological theorists, some monastic archaeologists were sceptical about gender (Coppack in Gilchrist et al 1996). When the patterns I proposed were eventually reassessed in purely positivist terms, the enduring value of a gendered perspective was conceded: nunneries really 'are different' (Bond 2003, 86; original italics).

\section{REFLECTIONS ON MEDIEVAL ARCHAEOLOGY AND THEORY}

In conclusion, it is clear that over the past 25 years theory has changed the questions that we ask about the Middle Ages, and it has transformed some aspects of how we study medieval archaeology. Processualism encouraged grand narratives on themes such as trade, the origins of towns and state formation, while the postprocessual concern with agency and meaning has fostered study of social identity, 

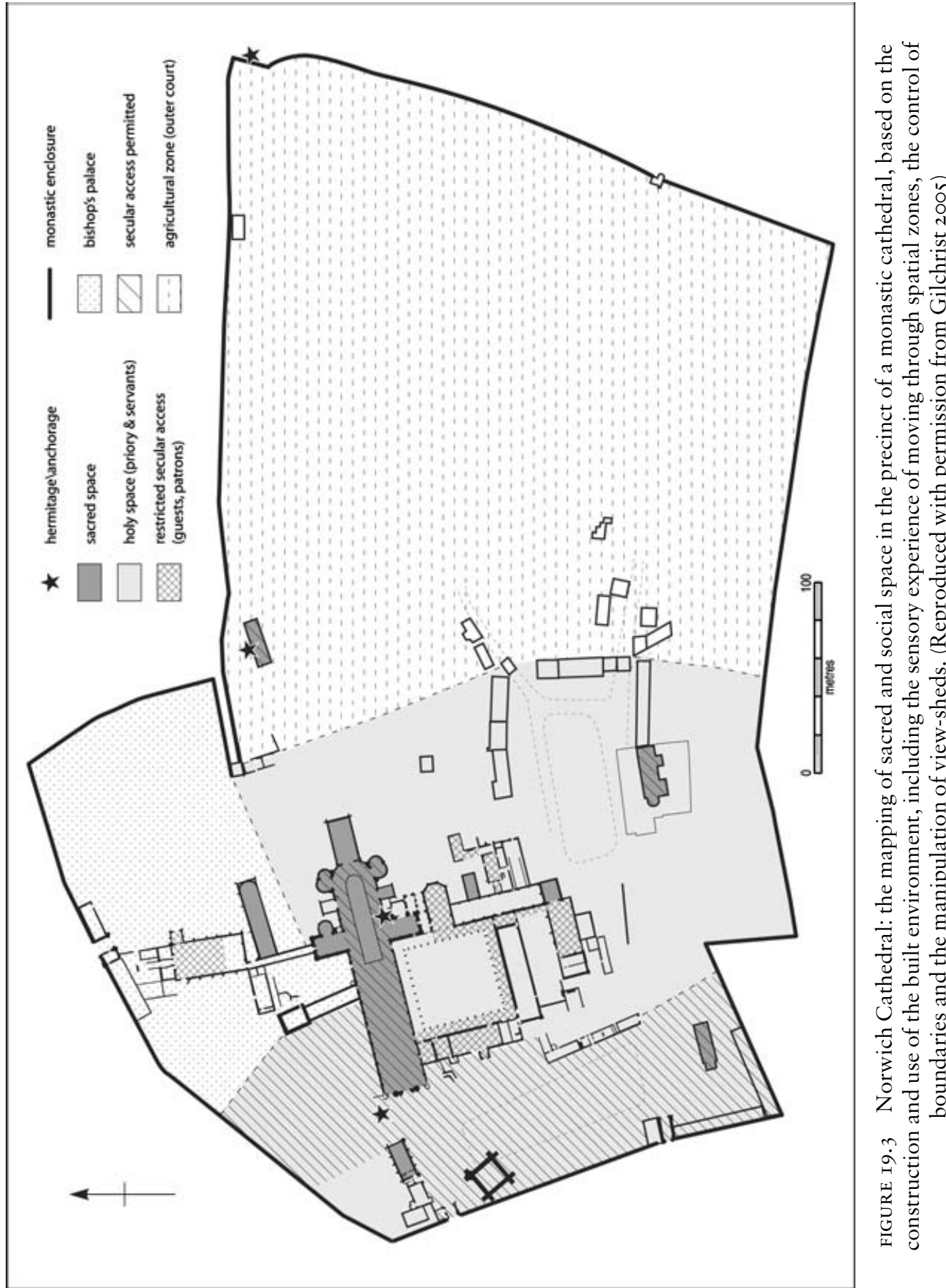
gender, supernatural belief, sensory perception and spatial experience. Theoretical perspectives have burgeoned especially in the study of spiritual beliefs in north-west Europe - pagan, Christian, and the processes of conversion and hybridity bridging them (eg Andrén 2007; Hedeager 200I; Price 2002; Carver 2003; Gilchrist 2008). In contrast, relatively little theoretical interpretation has yet been directed towards Byzantine Christianity (eg Ousterhout I99I; James 2003; Clark 2007), or the Jewish and Islamic ritual spaces of medieval Europe. The development of post-processual approaches may partly explain the apparent shift in interest away from previously core topics such as urbanism, in favour of the fields of burial and buildings archaeology. Much of the theory in medieval archaeology over the past few decades has taken a spatial approach; for example, theoretical treatments of urbanism have shifted from economic to spatial and symbolic analyses (K D Lilley 2004; O'Keefe 2004). The tremendous theoretical potential of material culture has yet to be realized, particularly in addressing issues such as materiality and embodiment.

A survey of interpretative trends in church archaeology reveals a thriving enclave of post-processualism, packed with insights brought by theories of practice, phenomenology, gender and personhood, combined in studies that retain empirical integrity. This innovation is especially noteworthy given the neglect of religion by the broader field of post-processual archaeology (Insoll 2004, 77). Church archaeology has been much more responsive to new theoretical thinking than some others, particularly in contrast with research in medieval landscape and rural settlement. The nature of the data may account for some differences: ecclesiastical buildings and associated iconographic evidence hold rich potential for addressing meaning. However, this divergence also reflects contrasting attitudes in our confidence to address agency via the medium of material culture. The realm of religious belief is more obviously amenable to such approaches, but rare exceptions in medieval landscape archaeology have demonstrated the possibility of addressing agency and reconciling social and environmental approaches (eg Dyer I990; Stocker and Everson 2006; POMLAS). The 'parachutist's' most daring leaps are sometimes made possible by years of 'truffle-hunting' sorties, gaining essential knowledge of the terrain.

Here, the salient point is that we cannot select between theoretical or empirical perspectives, nor is it easy to disentangle the tools for collecting and analysing archaeological data from the theoretical apparatuses that we use to interpret patterns in our evidence. New technologies such as Geographical Information Systems and Historic Landscape Characterization have aided empirical interrogation of the landscape (see Rippon, this volume), but their development has demanded a theoretical redefinition of the very concept of landscape itself. In particular, heritage managers have shifted from a definition of the landscape as a discrete physical and chronological entity, to a more conceptual perspective of landscape as a complex spatial and temporal matrix of perceptions (Florence Convention 2000, I and 7). Archaeologists may aim to achieve 'mitigated objectivity' — judging inferences made from archaeological evidence according to the degree of security of evidential claims (Wylie 2002, I77) - but ultimately all archaeological research is both empirical and theoretical.

The thesis that material culture is active and meaningful has accelerated the widespread growth of medieval social archaeology, but a stubborn rift has also been 
driven between approaches that can be grouped as social/theoretical versus economic/ scientific. Medieval archaeology continues to privilege empirical (quantitative) evidence over social (qualitative) analysis, and to perpetuate the processualist tendency to perceive a distinction between data and theory. Excavation reports, building and field surveys, corpora of sculpture and artefacts are considered to possess more enduring value if reported without theoretical interpretation or social commentary. This attitude is changing in some sectors, for example the more thematic, integrated excavation reports published for London's medieval monasteries (eg Thomas et al I997). Revolutions in archaeological publishing are likely to see increasing emphasis placed on interpretation in print media, with data archived electronically. This may provide an opportunity for more creative, interpretative approaches to the presentation of medieval archaeology, but it brings the danger of exacerbating the data/theory split.

Some aspects of early medieval archaeology continue to spar more enthusiastically with theory than their later medieval counterparts. Indeed, it might be argued that the internal periodization of medieval archaeology as a discipline inhibits more expansive theoretical and thematic experiment. To take just one example, later medieval burial archaeology has only recently begun to explore theoretical perspectives after 25 years of active theoretical research in the archaeology of early medieval burial. A range of issues would benefit from treatment across the longue duree that bridges the early and later Middle Ages, including capitalism, technology, religious belief, memory, foodways and ideas about the body, with due regard to the temporality of events (Harding 2005). Within medieval studies, the archaeological perspective of 'deep time' may even lend a distinctive voice to medieval archaeology. We have much to benefit from closer integration within our own discipline, as well as drawing inspiration from outside.

The purpose of our subject is the writing of medieval history in its widest sense, with the result that many medieval archaeologists prioritize communication with other fields of medieval studies over contact with prehistory or other historical archaeologies. ${ }^{16}$ More regular interaction with ideas current in prehistory can lend novel ideas to medieval archaeology — for example, 'structured deposition', a concept that has taken around 20 years to percolate from prehistoric, through Roman, to medieval archaeology (Hamerow 2006). And prehistorians could benefit equally from such an exchange: the conjoint use of historical and archaeological sources has produced some of the most convincing examples of post-processual interpretation. Indeed, it has been acknowledged that historical archaeology provides the most appropriate temporal resolution for the study of 'small-scale phenomena such as individual agency, inter-personal interactions and perception' (Bailey 2007, 20I). The defeatist may argue that the daunting abundance, complexity and interdisciplinarity of medieval archaeology are challenge enough, without the expectation to keep abreast of archaeological theory. But these are precisely the disciplinary traits that offer fertile capacity for a more meaningful medieval archaeology. A mature discipline should have the ambition to combine empirical rigour with theoretical innovation, and the imagination to integrate historical, scientific and social perspectives. This is 
a leap of faith, and one of the most important challenges for the next 25 years of medieval archaeology.

\section{ACKNOWLEDGEMENTS}

I am grateful to David Stocker, Matthew Johnson and Andrew Reynolds for their helpful comments on an early draft of this article. The opinions expressed are those of the author.

NOTES

${ }^{1}$ Hodges was adopting the famous metaphor used by the eminent historian of the French Annales school, Emmanuel Le Roy Ladurie (b I929), to distinguish between historians who are concerned exclusively with either the general (parachutists) or the particular (truffle-hunters).

2 The roots of culture-history may be found in the I9th-century emergence of national archaeologies and their emphasis on ethnic groups (Trigger I989, I74). Culture-history has remained the dominant approach of medieval archaeology in southern Europe, despite the differences created by respective Marxist and fascist regimes in the Balkans, Spain and Italy (see papers by Curta, Quirós Castillo, Augenti and Brogiolo, this volume).

3 The term paradigm was adopted by the philosopher of science Thomas Kuhn to describe the established mode of scientific practice in a given discipline. Such traditions of 'normal science' are occasionally disrupted and transformed by episodes of 'scientific revolution': 'the successive transition from one paradigm to another via revolution is the usual developmental pattern of mature science' (Kuhn, quoted in Preston 2008, 2I).

${ }^{4}$ For medieval archaeology's relationship to history, see discussions by Anders Andrén (I998, 25-36), Matthew Johnson (I999, I49-I6I) and John Moreland (200I).

5 This was a favoured phrase of John Hurst, one of the founders of the Society for Medieval Archaeology, and it was also regularly employed by the landscape historian W G Hoskins.

${ }^{6}$ Hodges' proposition that up to the 9th century trade was stimulated exclusively by elites has since been challenged on empirical evidence: the recording of coins from metal-detecting suggests that trade was more widespread and promulgated via local markets and regional trading places, described by archaeologists as 'productive sites' (Ulmschneider 2000). Søren Sindbaek (2007) has rekindled this debate through the application of complex network theory, arguing that Viking long-distance trade was tightly connected by a small group of individuals working through a select network of sites.
${ }^{7}$ A term promoted by the Annales school of French history, which stresses the inter-relationship of long, medium and short timescales.

${ }^{8}$ The editorial policy is to encourage more discursive theoretical and synthetic pieces, and the officers of the Society regularly encourage postgraduate students to publish theoretical articles in the journal; despite these efforts (unjustified) suspicion lingers of a conservative editorial policy!

9 See Gilchrist I999, I09-I45, for a gendered reading of the medieval castle from the perspective of elite female experience.

10 Tabula rasa refers to the thesis that humans are born a blank slate, and that their knowledge is formed through specific cultural experiences and sensory perceptions of the material world.

${ }^{11}$ Diaspora studies focus on identity in communities dispersed amongst other peoples, to explore issues of migration, colonization and the cultural processes of hybridity and creolization. The concept originally referred to communities in forced exile (in particular the Jewish Diaspora and the Black Atlantic), but has been applied to the archaeological study of prehistoric, Roman, post-medieval (I Lilley 2004; van Dommelen 2006) and most recently, medieval communities (Bowles 2007; Immonen 2007).

12 Gell employs the example of how the intricately carved prows of Trobriander canoes serve as psychological weapons to beguile Kula exchange partners. His discussion also refers to Salisbury Cathedral, but medieval archaeologists will be dismayed to hear that he was unimpressed by the monument itself, but enthralled instead by the 'technology of enchantment and the enchantment of technology' of the scaled matchstick model of the cathedral! (Gell I992, 47).

${ }^{13}$ Personhood refers to the condition of being a person in a particular social context; personhood is created and maintained through relationships with other people but also with things, places, animals and spiritual beings (Fowler 2004, 7).

${ }^{14}$ Developed by the French sociologist Pierre Bourdieu (d 2002), the influential concept of habitus refers to the practical logic and sense of order that guides our knowledge of the world 
(Bourdieu I977). This unconscious 'learned ignorance' reproduces social relations but still allows for individual human agency that can promote change.

${ }^{15}$ Developed by the British sociologist Anthony Giddens (b I938), structuration theory is based on the premise that social systems both result from human action and organize and reinforce human action. The 'duality of structure' has had considerable impact in archaeology; it acknowledges the interdependence of social structure and human agency, thus power is perceived to be enabling as well as constraining (Giddens I984, 374).

16 More pragmatic reasons may also be cited for improved communication. The panels of funding bodies and government research assessments for archaeology tend to be dominated by prehistorians - it would benefit medieval archaeologists to convey the significance of their research in terms that the wider subject will recognize.

\section{BIBLIOGRAPHY}

Altenberg, K, 2003 Experiencing Landscapes. A Study of Space and Identity in Three Marginal Areas of Medieval Britain and Scandinavia, Lund Studies in Medieval Archaeology 3I, Lund

Andrén, A, I993 'Doors to other worlds: Scandinavian death rituals in Gotlandic perspectives', Journal of European Archaeology I, 33-56

Andrén, A, I998 Between Artifacts and Texts. Historical Archaeology in Global Perspective, Plenum, London

Andrén, A, I999 'Landscape and settlement as utopian space', in C Fabech and J Ringtved (eds), Settlement and Landscape, 383-393, Jutland Archaeological Society, Århus

Andrén, A, 2000 'Re-reading embodied texts — an interpretation of rune-stones', Current Swedish Archaeology 8, 7-32

Andrén, A, 2007 'Behind Heathendom. Archaeological studies of Old Norse religion', Scottish Archaeological Review 27, 105-I38

Andrén, A, Jennbert, K, Raudvere C, (eds) 2006 Old Norse Religion in Long-Term Perspectives, Nordic Academic Press, Lund

Arnold, C J, 1988 An Archaeology of the Early Anglo-Saxon Kingdoms, Routledge, London

Bailey,G, 2007 'Time perspectives, palimpsests and the archaeology of time', Journal of Anthropological Archaeology 26, 198-223

Barrett J H, 208 'What caused the Viking Age?' Antiquity 82, 67I-68 5

Barrett J H, and Richards, M P 2005, 'Identity, gender, religion and economy: new isotope and radiocarbon evidence for marine resource intensification in early historic Orkney, Scotland, UK', European Journal of Archaeology 7, 249-27I

Bianco C, I993 'Ecclesiastical buildings in use', in J Hunter and I Ralston (eds), Archaeological Resource Management in the UK. An Introduction, 89-99, Sutton, Stroud

Biddick, K, I998, The Shock of Medievalism, Duke University Press, Durham NC

Blair, J, 2005 The Church in Anglo-Saxon Society, Oxford University Press, Oxford

Blair, J and Pyrah, C, (eds) I996 Church Archaeology: Research Directions for the Future, Council for British Archaeology Research Report I04, York

Bond, C J, 2003 'English medieval nunneries: buildings, precincts, and estates', in D Wood (ed), Women and Religion in Medieval England, 46-90, Oxbow, Oxford

Bond, C J, 2004 Monastic Landscapes, Tempus, Stroud

Bourdieu, P, I977 Outline of a Theory of Practice, Cambridge University Press, Cambridge

Bowles, C R, 2007 Rebuilding the Britons. The Postcolonial Archaeology of Culture and Identity in the Late Antique Bristol Channel Region, British Archaeological Reports 452, Oxford

Brown, D, 2005, 'Pottery and manners', in Carroll et al (eds) 2005, 87-99

Carelli, P, I997 'Thunder and lightning, magical miracles. On the popular myth of thunderbolts and the presence of Stone Age artefacts in medieval deposits', in H Andersson, P Carelli and 
L Ersgard (eds), Visions of the Past. Trends and Traditions in Swedish Medieval Archaeology, 393-417, Lund Studies in Medieval Archaeology I9, Lund

Carroll, M, Hadley, D M and Willmott, H (eds), 2005 Consuming Passions. Dining from Antiquity to the Eighteenth Century, Tempus, Stroud

Carver, M O H, I998 Sutton Hoo: Burial Ground of Kings? University of Pennsylvania Press, London

Carver, M O H, 200I 'Why that? Why there? Why then? The politics of early medieval monumentality', in A Macgregor and H Hamerow (eds), Image and Power in the Archaeology of Early Medieval Britain: Essays in Honour of Rosemary Cramp, Oxbow, Oxford, I-22

Carver, M O H (ed), 2003 The Cross Goes North: Processes of Conversion in Northern Europe, Boydell, Woodbridge

Clark, D L C, 2007 'Viewing the liturgy: a space syntax study of changing visibility and accessibility in the development of the Byzantine church in Jordan', World Archaeology 39: I, 84-IO4

Clarke, D V, 2007 'Reading the multiple lives of Pictish symbol stones', Medieval Archaeology 5I, I9-39

Creighton, $\mathrm{O} \mathrm{H}, 2002$ Castles and Landscape, Continuum, London

Cumberpatch, C G, I997 'Towards a phenomenological approach to the study of medieval pottery', in C G Cumberpatch and P W Blinkhorn (eds), Not So Much a Pot, More a Way of Life, I25-I52, Oxbow, Oxford

Dickinson, T, 2005 'Symbols of protection: the significance of animal-ornamented shields in early Anglo-Saxon England', Medieval Archaeology 49, I09-I63

Dixon, P, I990 'The donjon of Knaresborough: the castle as theatre', Châtean Gaillard I4, I2 I-I39

Dyer, C, I990 'Dispersed settlements in medieval England. A case study of Pendock, Worcestershire', Medieval Archaeology 34, 97-I2I

Eaton, T, 2000 Plundering the Past. Roman Stonework in Medieval Britain, Tempus, Stroud

Egan, G, I998 The Medieval Household. Daily Living cII5O-CI450. Medieval Finds from Excavations in London 6, Museum of London, London

Everson, P, I996 'Bodiam Castle, East Sussex: a castle and its designed landscape', Château Gaillard $\mathrm{I} 7,79-84$

Fairclough, G, I992 'Meaningful constructions - spatial and functional analysis of medieval buildings', Antiquity 66, 348-366

Fernie, E, I988 'Contrasts in methodology and interpretation of medieval ecclesiastical architecture', The Archaeological Journal I45, 344-364

FitzPatrick, E and Gillespie, R (eds), 2006 The Parish in Medieval and Early Modern Ireland. Community, Territory and Building, Four Courts Press, Dublin

Fleming, A, 2007 'Don't bin your boots!', Landscapes 8:I, 85-99

Florence Convention http://www.coe.int/t/dg $/$ cultureheritage/Conventions/Landscape (accessed 4 September 2008)

Fowler, C, 2004 The Archaeology of Personhood. An Anthropological Approach, Routledge, London

Gaimster, D, I999 'The Baltic ceramic market, cI200-I600: an archaeology of the Hansa', Fennoscandia Archaeologica I6, 59-69

Gansum, T and Oestigaard, T 2004, 'The ritual stratigraphy of monuments that matter', European Journal of Archaeology 7:I, 6I-79

Gell, A, I992 'The technology of enchantment and the enchantment of technology', in J Coote and A Shelton (eds), Anthropology, Art and Aesthetics, 40-63, Clarendon, Oxford

Gerrard, C, 2003 Medieval Archaeology. Understanding Traditions and Contemporary Approaches, Routledge, London 
Giddens, A, 1984 The Constitution of Society, Polity Press, Cambridge

Gilchrist, R, 1994 Gender and Material Culture: the Archaeology of Religious Women, Routledge, London

Gilchrist, R, 1999 Gender and Archaeology: Contesting the Past, Routledge, London

Gilchrist, R, 2005 Norwich Cathedral Close: the Evolution of the English Cathedral Landscape, Boydell, Woodbridge

Gilchrist, R, 2008 'Magic for the dead? The archaeology of magic in later medieval burials', Medieval Archaeology 52, I-4I

Gilchrist, R, Dyer, C, Scott, E, Gero, J and Coppack, G, I996 'Review feature: gender and material culture', Cambridge Archaeological Journal 6:I, II9-I36

Gilchrist, R, and Sloane, B, 2005 Requiem: the Medieval Monastic Cemetery in Britain, Museum of London Archaeology Service Monograph, London

Giles, K, $2000 \mathrm{a}$ An Archaeology of Social Identity. Guildhalls in York, CI350-I630, British Archaeological Report 315, Oxford

Giles, K, $2000 \mathrm{~b}$ 'Marking time? A I 5 th-century liturgical calendar in the wall paintings of Pickering parish church', Church Archaeology 4, 42-5I

Giles, K, 2007 'Seeing and believing: visuality and space in pre-modern England', World Archaeology 39:I, I05-I2I

Gosden, C, 200I 'Making sense: archaeology and aesthetics', World Archaeology 33:2, I63-I67

Graves, C P, 1989 'Social space in the English medieval parish church', Economy and Society I8, $297-322$

Graves, C P, 2000 The Form and Fabric of Belief: The Archaeology of Lay Experience in Medieval Norfolk and Devon, British Archaeological Reports 3II, Oxford

Graves, C P, 2007 'Sensing and believing: exploring worlds of difference in pre-modern England: a contribution to the debate opened by Kate Giles', World Archaeology 39:4, 5I 5-53I

Graves, C P, 2008 'From an archaeology of iconoclasm to an anthropology of the body. Images, punishment and personhood in England, I 500-I660', Current Anthropology 49:I, 35-57

Hacker, P M S, 2007 Human Nature: the Categorical Framework, Blackwell, Oxford

Hadley, D M, 2004 'Negotiating gender, family and status in Anglo-Saxon burial practices, c600-950', in L Brubaker and J M H Smith (eds), Gender in the Early Medieval World. East and West, 300-900, 30I-323, Cambridge University Press, Cambridge

Hadley, D M, 2005 'Dining in disharmony in the Later Middle Ages', in Carroll et al (eds) 2005, IOI-II9

Hall, M A, 200I 'An ivory knife handle from the High Street, Perth, Scotland: consuming ritual in a medieval borough', Medieval Archaeology 45, I69-I88

Hall, M A, 2005 'Burgh mentalities: a town-in-the-country case study of Perth, Scotland', in K Giles and C Dyer (eds), Town and Country in the Middle Ages, 2II-228, Society for Medieval Archaeology Monograph 22, Maney Publishing, Leeds

Halsall, G, I996 'Female status and power in early Merovingian central Austrasia: the burial evidence', Early Medieval Europe 5:I, I-24

Hamerow, H, 2006 “"Special deposits” in Anglo-Saxon settlements', Medieval Archaeology 50, $\mathrm{I}-30$

Harding, J, 2005, 'Rethinking the great divide: long-term structural history and the temporality of event', Norwegian Archaeological Review 38:2, 88-IOI

Härke, H, I990 'Warrior graves? The background of the Anglo-Saxon weapon burial rite', Past and Present $\mathrm{I} 26,22-43$

Härke, H, I998 'Archaeologists and migrations: a problem of attitude?', Current Anthropology 39:I, I9-45 
Härke, H, 2007 'Ethnicity, "race" and migration in mortuary archaeology: an attempt at a short answer', in S Semple and H Williams (eds), Early Medieval Mortuary Practices, I2-I8, AngloSaxon Studies in Archaeology and History I4, Oxford

Hedeager, L, 200I 'Asgard reconstructed? Gudme - a "central place”' in the north', in M de Jong and F Theuws with C van Rhijn (eds), Topographies of Power in the Early Middle Ages, 467-507, Brill, Leiden

Hedeager, L, 2007 'Scandinavia and the Huns: an interdisciplinary approach to the migration era', Norwegian Archaeological Review 40:I, 42-58

Hillier, B, and Hanson, J, I984 The Social Logic of Space, Cambridge University Press, Cambridge

Hingley, R, 2005 Globalizing Roman Culture: Unity, Diversity, Empire, Routledge, London

Hinton, D A, I999 “'Closing” and the Later Middle Ages', Medieval Archaeology 43, I72-182

Hinton, D A, 2005 Gold \& Gilt, Pots \& Pins. Possessions and People in Medieval Britain, Oxford University Press, Oxford

Hodder, I, I982a Symbols in Action: Ethnoarchaeological Studies of Material Culture, Cambridge University Press, Cambridge

Hodder, I, I982b The Present Past, Batsford, London

Hodges, R, I982 Dark Age Economics: the Origins of Towns and Trade, AD 600-I000, Duckworth, London

Hodges, R, I983 'New approaches to medieval archaeology', in D A Hinton (ed), 25 Years of Medieval Archaeology, 24-32, Department of Prehistory and Archaeology and the Society for Medieval Archaeology, Sheffield

Hodges, R, I989, 'Parachutists and truffle-hunters: at the frontiers of archaeology and history', in M Aston, D A Austin and C Dyers (eds), Rural Settlements of Medieval England: Studies Dedicated to Maurice Beresford and John Hurst, 287-306, Blackwell, Oxford

Immonen, V, 2007 'Defining a culture: the meaning of Hanseatic in medieval Turku', Antiquity 8I, $720-732$

Ingold, T, 2007 'Materials against materiality', Archaeological Dialogues I4:I, I-I6

Ingold, T, 2000 'The temporality of landscape', in T Ingold, The Perception of the Environment, I89-208, Routledge, London

Insoll, T, 2004 Archaeology, Religion, Ritual, London, Routledge

James, L, 2003 'Colour and meaning in Byzantium', Journal of Early Christian Studies Iı:2, $223-233$

Johnson, M H, I993 Housing Culture. Traditional Architecture in an English Landscape, University College London Press, London

Johnson, M H, I999 Archaeological Theory. An Introduction, Blackwell, Oxford

Johnson, M H, 2002 Behind the Castle Gate: from Medieval to Renaissance, Routledge, London

Johnson, M H, 2007 Ideas of Landscape, Blackwell, Oxford

Jones, M, 2002 The Secret Middle Ages. Discovering the Real Medieval World, Sutton, Stroud

Jope, E M, I972 'Models in medieval studies', in D L Clarke (ed), Models in Archaeology, 963-990, Methuen, London

Kopytoff, I, I986 'The cultural biography of things: commodification as process', in A Appadurai (ed), The Social Life of Things. Commodities in Cultural Perspective, 64-9I, Cambridge University Press, Cambridge

Kristjánsdóttir, S, 2004 The Awakening of Christianity in Iceland, University of Gothenburg Archaeological Thesis Series B No 3I, Gothenburg

Kristoffersen, S and Oestigaard, T 2008, "'Death myths": performing rituals and variation in corpse treatment during the Migration Period in Norway', in F Fahlander and T Oestigaard (eds), The Materiality of Death. Bodies, Burials, Beliefs, I27-I39, British Archaeological Report International Series I768, Oxford 
Lane, P, 200I 'The archaeology of Christianity in global perspective', in T Insoll (ed), Archaeology and World Religion, I48-I8I, Routledge, London

Latour, B, 2005 Reassembling the Social: an Introduction to Actor-network Theory, Oxford University Press, Oxford

Liddiard, R, 2005 Castles in Context. Power, Symbolism and Landscape, I066-I500, Windgather Press, Oxford

Lilley, I, 2004 'Diaspora and identity in archaeology: moving beyond the Black Atlantic', in L Meskell and R W Preucel (eds), A Companion to Social Archaeology, 287-3I2, Blackwell, Oxford

Lilley, K D, 2004 'Cities of God? Medieval urban forms and their Christian symbolism', Transactions of the Institute of British Geographers, New Series 29, 296-3I3

Lucy, S, 2000 The Anglo-Saxon Way of Death, Sutton, Stroud

Luoto, K 2007 'Artefacts and enculturation - Examples of toy material from the medieval town of Turku', in V Immonen, M P Lempiäinen and U Rosendahl (eds), Hortus novus. Fresh Approaches to Medieval Archaeology in Finland, IO-20, Archaeologia Medii Aevi Finlandiae XIV

Meskell, L, and Joyce, R, 2003 Embodied Lives. Figuring Ancient Maya and Egyptian Experience, Routledge, London

Moreland, J, I99I 'Method and theory in medieval archaeology in the I990s', Archaeologia Medievale I8, 7-42

Moreland, J, I999 'The world(s) of the cross', World Archaeology 3I:2, I94-2I3

Moreland, J, 200I Archaeology and Text, Duckworth, London

Morris, R, 1983 The Church in British Archaeology, Council for British Archaeology Research Report 47, London

Morris, R, 1989 Churches in the Landscape, Phoenix, London

Nøttveit, O, 2006 'The kidney dagger as a symbol of masculine identity - the ballock dagger in the Scandinavian context', Norwegian Archaeological Review 39:2, I38-I 50

O'Keefe, T, 2004, 'Medieval towns, modern signs, identity inter-spaces: some reflections in historical archaeology', in E Casella and C Fowler (eds), The Archaeology of Plural and Changing Identities: Beyond Identification, I I-32, Springer, New York

Ousterhout, R, I99I 'The holy space. Architecture and the liturgy', in S Safran (ed), Heaven on Earth. Art and the Church in Byzantium, 8I-120, University Park, Pennsylvania

Parker Pearson, M and Ramilisonina, 1998 'Stonehenge for the ancestors: the stones pass on the message', Antiquity 72, 308-326

Pestell, T, 2005 'Using material culture to define holy space: the Bromholm Project', in S Hamilton and A Spicer (eds), Defining the Holy. Sacred Space in Medieval and Early Modern Europe, I6I-I86, Ashgate, Aldershot

Pluskowski, A G, 2005 'Narwhals or unicorns? Exotic animals as material culture in medieval Europe', European Journal of Archaeology 7:3, 29I-3I3

Pluskowski, A (ed), 2007 Breaking and Shaping Beastly Bodies, Animals as Material Culture in the Middle Ages, Oxbow, Oxford

POMLAS: Perceptions of Medieval Landscapes and Settlement http://www.britarch.ac.uk/msrg/ pomlas.htm (accessed 25 July 2008)

Preston, J M, 2008 Kuhn's 'The Structure of Scientific Revolutions'. A Reader's Guide, Continuum, London

Price, N S, 2002 The Viking Way. Religion and War in Late Iron Age Scandinavia, Department of Archaeology and Ancient History, Uppsala

Randsborg, K, I980 The Viking Age in Denmark: the Formation of a State, St Martin's Press, New York 
Randsborg, K, I99I The First Millennium AD in Europe and the Mediterranean, Cambridge University Press, Cambridge

Renfrew, C and Bahn, P, I991 Archaeology: Theories, Methods and Practice, Thames and Hudson, London

Richardson, A, 2003 'Gender and space in English royal palaces $c$ II60- $c$ I5 477: a study in access analysis and imagery', Medieval Archaeology 47, I3 I-I65

Rodwell, W, I997 'Landmarks in Church Archaeology', Church Archaeology I, 5-I6

Rodwell, W, 2005 The Archaeology of Churches, Tempus, Stroud

Roffey, S, 2007 The Medieval Chantry Chapel: an Archaeology, Boydell, Woodbridge

Rowley-Conwy, P A, 2004 'How the West was lost: a reconsideration of agricultural origins in Britain, Ireland and southern Scandinavia', Current Anthropology 45, 83-II 3

Rybina, E A 1992 'Recent finds from Excavations in Novgorod', in The Archaeology of Novgorod, Russia, I60-I92, Society for Medieval Archaeology Monograph I3, Lincoln

Sahlins, M, 1974 Stone Age Economics, Aldine, New York

Saunders, T, 2002 'Power relations and social space: a study of the late medieval archbishop's palace in Trondheim', European Journal of Archaeology 5:I, 89-I I I

Sindbaek, S M, 2007 'The small world of the Vikings: networks in early medieval communication and exchange', Norwegian Archaeological Review 40:I, 59-74

SMA, I987 'Archaeology and the Middle Ages. Recommendations by the Society for Medieval Archaeology to the Historic Buildings and Monuments Commission for England', Medieval Archaeology 3I, I-I2

Sofaer, J, 2006 The Body as Material Culture, Cambridge University Press, Cambridge

Stocker, D, 1997 'Fons et origo. The symbolic death, burial and resurrection of English font stones', Church Archaeology I, I7-25

Stocker, D, and Everson, P, I990 'Rubbish recycled: a study of the re-use of stone in Lincolnshire', in D Parsons (ed), Stone Quarrying and Building in England AD 43-I525, 83-IOI, Phillimore, Chichester

Stocker, D and Everson, P, 2006 Summoning St. Michael: Early Romanesque Towers in Lincolnshire, Oxbow, Oxford

Stoodley, N, 1999 The Spindle and the Spear, British Archaeological Report 288, Oxford

Stoodley, N, 2000 'From the cradle to the grave: age organization and the early Anglo-Saxon burial rite', World Archaeology 3i:3, 456-472

Sykes, N J, 2007 The Norman Conquest: A Zooarchaeologial Perspective, British Archaeological Report International Series I656, Oxford

Thomas, C, Sloane, B and Phillpotts, C, 1997 Excavations at the Priory and Hospital of St Mary Spital, London, Museum of London Archaeology Service Monograph I, London

Tilley, C, 2006 'Objectification', in Tilley et al (eds) 2006, 60-73

Tilley, C, Keane, W, Küchler, S, Rowlands, M and Spyer P (eds), 2006 Handbook of Material Culture, Sage, London

Trigger, B G, 1989 A History of Archaeological Thought, Cambridge University Press, Cambridge

Turner, S, 2006 Making a Christian Landscape. The Countryside in Early Medieval Cornwall, Devon and Wessex, Exeter University Press, Exeter

Ulmschneider, K, 2000 Markets, Minsters, and Metal-Detectors, British Archaeological Reports 307, Oxford

Van Dommelen, P 2006 'Colonial matters: material culture and postcolonial theory in colonial situations', in Tilley et al (eds) 2006, I04-I24

Welinder, S, I998 'The cultural construction of childhood in Scandinavia, 3500 BC-I350 AD', Current Swedish Archaeology 6, I85-204 
Williams, H, I997 'Ancient landscapes and the dead: the reuse of prehistoric and Roman monuments as early Anglo-Saxon burial sites', Medieval Archaeology 4I, I-32

Williams, H, 2003 'Remembering and forgetting the medieval dead', in H Williams (ed), Archaeologies of Remembrance: Death and Memory in Past Societies, 227-254, Plenum, New York

Williams, H, 2005 'Keeping the dead at arm's length: memory, weaponry and early medieval mortuary technologies', Journal of Social Archaeology 5:2, 253-275

Williams, H, 2006 Death and Memory in Early Medieval Britain, Cambridge University Press, Cambridge

Williamson, T, 2003 Shaping Medieval Landscapes, Windgather Press, Oxford

Wylie, A, 2002 Thinking from Things. Essays in the Philosophy of Archaeology, University of California Press, Berkeley

Zadora-Rio, E, 2003 'The making of churchyards and parish territories in the early-medieval landscape of France and England in the 7 th-I2th centuries: a reconsideration', Medieval Archaeology 47, I-20 